\title{
Figurative Idiomatic Competence: An Analysis of EFL Learners in Vietnam
}

\author{
Huong Quynh Tran \\ Hanoi National University of Education, Vietnam
}

\begin{abstract}
This article explores the figurative idiomatic competence of language learners and their perceptions of idiom learning in an EFL context. As a descriptive statistics case study, it investigates the students' knowledge of 50 idioms collected from the lists of frequently used idioms by Grant (2007) and Liu (2003) and from two common idiom textbooks. The findings show the students' poor idiomatic competence, especially their very limited knowledge of the frequently used idioms. The analysis uncovers the paradox between the students' situation of using and learning idioms and their desires to learn. The study argues that figurative idiomatic competence should receive adequate attention in the learning process. Figurative idioms should be inclusively taught with the skills of negotiation of meaning. Also, learners should be exposed to a variety of idioms which are not only from traditional English-speaking countries but also from the countries of the outer- and expanding-circle contexts.
\end{abstract}

Idiom learning has recently attracted a greater level of interest in English learning contexts, from online learning websites to language textbooks. The website BBC Learning English, for example, has introduced a series of idiom-related sections called "Today's Phrase" and "The English We Speak." Additionally, the latest coursebooks widely utilized in teaching English programs in Asia put more emphasis on idioms in use. This tendency reflects the requisite necessity of idioms in the process of learning English as a foreign language (EFL). Indeed, the ability to use idioms helps establish figurative competence in the communicative competence model by Celce-Murcia (2008).

Within this trend, the assessment of how well Asian language learners use idioms in communication is a growing need. English users in Asia, such as pupils, university graduates, and teachers of English, have to be qualified in accordance to the requirements for English as a second / foreign language (ESL / EFL) in the national curricula. For example, in Vietnam, English language learners are evaluated either in the Common European Framework of Reference (CEFR) or in international testing systems such as TOEFL, IELTS, and TOEIC. The National Foreign Languages 2020 Project in Vietnam states that the overall English proficiency of English teachers at secondary schools and of university graduates certified to teach English as a foreign language (TEFL) is expected to be at the $\mathrm{C} 1$ level in the CEFR or equivalent. One of the indicators, as listed in the CEFR listening skill band descriptors, is "I can understand a wide range of idiomatic expressions and colloquialisms" (Council of Europe, 2012, p. 66). In the IELTS speaking band descriptors, mastery of idiomatic expressions is mentioned as a criterion of lexical resource from Band 7 onward, which is equivalent to the $\mathrm{C} 1$ level in the CEFR. In Band

Language Education in Asia, 2013, 4(1), 23-38. http://dx.doi.org/10.5746/LEiA/13/V4/I1/A3/Tran 
7, language users are expected to be able to "use some less common and idiomatic vocabulary" (British Council, n.d., p. 1).

However, idiom teaching might have not received adequate attention in foreign language teaching contexts yet (Tran, 2012; Vasiljevic, 2011). Few teachers in Asia are aware of the roles of idioms in communicative competence. They may have encountered difficulties in choosing a suitable teaching method, selecting idioms, and explaining the use of an idiom in its appropriate contexts. Many teachers tend to avoid idioms in their language and teaching (Tran, 2012). Although there have been significant studies of learning and teaching approaches for idioms (Cooper, 1999; Lennon, 1998; Levorato, Nesi, \& Cacciari, 2004; Prodromou, 2003; Zyzik, 2011), research on the assessment of the idiomatic competence of EFL learners in Asia is limited.

Therefore, this study focused on the figurative idiomatic competence of Vietnamese EFL language learners at a leading pedagogical university in Vietnam. The findings revealed the participants' low level of figurative idiom competence. This poor idiomatic competence might also be found in other Asian countries.

\section{Figurative Idioms}

\section{Literature Review}

Many attempts have been made to define and classify idioms (e.g., Cooper, 1999; Grant \& Bauer, 2004; Lennon, 1998; Simpson \& Mendis, 2003). Some scholars such as Lennon (1998) have emphasized the continuous scale of idiomaticity in language. Others such as Zyzik (2011) have focused on the fixed characteristic in the syntax of an idiom. In this viewpoint, the constituents of an idiom appear to co-occur (words that comprise an idiom may not be substituted or transformed). Idioms can also be categorized by the scale of non-literal meaning (e.g., Fernando, 1996), or length (e.g., Makkai, 1972).

The notion of figurative idioms in this study follows Grant and Bauer's (2004) definition and classification in which the degree of compositionality and figurative interpretation is counted. For example, the phrase "my cup of tea" in "some people fancy tennis, but it's not my cup of tea" is a figurative idiom. This idiom does not refer to a drink but to something or someone that one finds pleasing. In figurative idioms, there are figurative and literal meanings; therefore, listeners have to decide the meaning of a figurative idiom in a particular context.

\section{Idiomatic Competence}

Idiomatic or figurative competence has recently been discussed in accordance with communicative competence, which was inspired by Chomsky (1965) and Hymes (1972), Canale and Swain (1980), and Celce-Murcia $(1995,2008)$. In the revised model of communicative competence by Celce-Murcia (2008), the ability to use idioms is regarded as a component of formulaic competence. Formulaic competence refers to the selection and use of fixed chunks or stretches of language in communication (Celce-Murcia, 2008). As part of formulaic competence, idiomatic competence is the ability to appropriately communicate with idioms in the roles of both an addressor and an addressee (Buckingham, 2006; Burke, 1988). It helps communicators fully encode and decode the meaning of a conversation.

Knowles (2004) described the learning process in five steps ranging from familiarization, recognition, and comprehension to mastery and automaticity. When students reach automaticity, they are able to confidently communicate in the language they are learning. Automaticity can be achieved through the practice of phrases and thought groups and the 
exposure to the target language, Knowles (2004) argues. This implies that language learners should be exposed to idiomatic expressions and should have intensive practice to be able to use idioms for communication.

\section{Measuring Idiomatic Competence}

Measuring idiomatic competence is problematic. Although the aspects of knowing a word can be academically described, designing a test for measuring multiple traits of words, such as forms, positions, functions, and meaning, tend to be unfeasible (Zareva, Schwanenflugel, \& Nikolova, 2005). Some frequently used models for measuring vocabulary knowledge focus on two dimensions - the size and the quality (Nation, 2001; Richards, 1976). Other models, such as Henriksen's (1999), may add the receptive and productive control of vocabulary in communication to establish a third dimension of vocabulary development. Idioms are considered multi-unit words; therefore, a measurement of idiomatic competence may follow the above attributes. It should determine the breadth and depth of idioms that a learner is able to comprehend and use for communication.

\section{Idiom-Related Research in Language Learning and Use}

Studies of idioms in language learning and use can be divided into three main categories. Firstly, early research concerned the constitution of idioms (e.g., Fernando, 1996; Grant \& Bauer, 2004; Makkai, 1972). Secondly, a great deal of research focused on methods of teaching idioms (e.g., Buckingham, 2006; Copper, 1999; Lennon, 1998; Tran, 2012; Vasiljevic, 2011; Wray, 2000; Zyzik, 2009). These studies attempted to find effective ways of teaching idioms for language learners in ESL / EFL contexts. For example, Zyzik (2009) discussed some activities for teaching idiom comprehension as well as literal and figurative meanings. Tran (2012) suggested four-skill-integrated tasks for teaching idioms. Vasiljevic (2011) argued that using conceptual metaphors and code switching to the mother tongue in discussing idiom meaning may be effective teaching methods. Thirdly, selection of idioms to be learned is also of research interest. Liu's (2003) and Simpson and Mendis' (2003) have focused on idioms which are the most frequently used in different contexts by using a corpus-based research approach. However, there is little research that explores the idiomatic competence of language users in EFL contexts. Therefore, this empirical study is an attempt to partly fill this gap in idiom-related research on language learning and use.

\section{Research Questions}

The study seeks the answers to the following questions:

1. To what extent do EFL students know and use frequently used idioms?

2. To what extent do they desire to know and use frequently used idioms?

\section{Methods and Procedure}

The research design is a descriptive statistics case study, which is a combination of descriptive statistics research and a case study. Descriptive statistics research is used to explore and describe people's characteristics, perceptions, and viewpoints (Brown \& Rodgers, 2002). In this study, the research questions focus on the students' understanding of their knowledge and use of idioms. A case study, on the other hand, uses a case or cases as an instrument to obtain insight into a question (Stake, 1995). This design helps explore multiple aspects of the idiomatic competence of language learners. The answers to the two research questions in the present study are drawn from a measuring test on idiomatic competence, questionnaires, focus groups, and observations. These data collection tools were treated as triangulations to assure data reliability. 
Seventy-four students in Year 1 and Year 2 at a university of education in Vietnam were the informants of the study. The former group was comprised of 47 freshmen who have learnt English for between 4 and 10 years. They were at the pre-intermediate level of English. The latter was a group of 27 sophomores at the intermediate level of English. They were pre-service teachers of English, so they were learning English in the roles of language learners and preservice teachers. They were expected to achieve C1 in the CEFR or the equivalent after four years at the university.

The data collection procedure was prepared and conducted in three stages. Firstly, 50 figurative idioms were collected to design the test. The idioms and the questionnaires were grouped into two sets. The selection of the first set of 20 idioms was grounded in the findings of the corpus-based studies by Grant (2007), Liu (2003), and Simpson and Mendis (2003). These scholars presented a list of frequently used figurative idioms in several corpora. These idioms, regarded as fixed phrases, were searched for with advanced techniques in the Google search engine to estimate the number of online documents for each idiom. There was a very wide range in the number results from the Google search of the different idioms, but most were over two million per idiom. The second set of thirty idioms was selected from the books on idioms that were available in Vietnam; if the search results in Google search were over two million, the idiom was included. 
Table 1

List of Selected Figurative Idioms

\begin{tabular}{|c|c|c|c|c|c|}
\hline & Idioms & $\begin{array}{l}\text { Google } \\
\text { search } \\
\text { results }\end{array}$ & & Idioms & $\begin{array}{l}\text { Google } \\
\text { search } \\
\text { results }\end{array}$ \\
\hline 1. & a piece of cake & $9,950,000$ & 26. & speak your mind & $60,000,000$ \\
\hline 2. & not my cup of tea & $3,310,000$ & 27. & cross your mind & $30,600,000$ \\
\hline 3. & add fuel to the fire & $6,660,000$ & 28. & in the long run & $253,000,000$ \\
\hline 4. & make up one's mind & $10,870,000$ & 29. & at the end of the day & $123,000,000$ \\
\hline 5. & off the top of one's head & $26,000,000$ & 30. & black and white & $391,000,000$ \\
\hline 6. & have/get a say/voice in & $21,500,000$ & 31. & wouldn't hurt a fly & $2,640,000$ \\
\hline 7. & all of a sudden & $60,800,000$ & 32. & be your bread and butter & $5,930,000$ \\
\hline 8. & be over one's head & $4,660,000$ & 33. & middle of the road & $12,400,000$ \\
\hline 9. & a rule of thumb & $24,000,000$ & 34. & down to earth & $73,100,000$ \\
\hline 10. & push the envelope & $3,120,000$ & 35. & over the moon & $8,510,000$ \\
\hline 11. & bits and pieces & $15,700,000$ & 36. & your heart sinks & $2,730,000$ \\
\hline 12. & thinking on my feet & $8,810,000$ & 37. & a long face & $3,280,000$ \\
\hline 13. & draw the line between & $5,490,000$ & 38. & hit the sack & $4,770,000$ \\
\hline 14. & take my word for it & $33,000,000$ & 39. & odds and ends & $10,100,000$ \\
\hline 15. & goes to show & $78,000,000$ & 40. & call it a day & $5,320,000$ \\
\hline 16. & down the line & $20,700,000$ & 41. & have a ball & $14,700,000$ \\
\hline 17. & get to the bottom of things & $2,601,000$ & 42. & drop me a line & $60,200,000$ \\
\hline 18. & have second thoughts & $5,800,000$ & 43. & flesh and blood & $8,690,000$ \\
\hline 19. & out of the blue & $26,000,000$ & 44. & make yourself at home & $14,000,000$ \\
\hline 20. & I can take it or leave it & $11,400,000$ & 45. & under the weather & $5,720,000$ \\
\hline 21. & if all else fails & $5,680,000$ & 46. & make ends meet & $10,300,000$ \\
\hline 22. & in your shoes & $146,000,000$ & 47. & a know-it-all & $22,400,000$ \\
\hline 23. & on top of the world & $11,800,000$ & 48. & paint a picture & $3,400,000$ \\
\hline 24. & make it big & $5,890,000$ & 49. & go all out & $23,000,000$ \\
\hline 25. & snowed under & $2,160,000$ & 50. & lift a finger & $10,800,000$ \\
\hline
\end{tabular}

Secondly, one measurement test and two questionnaires were designed with the selected 50 idioms. The test (see Appendix) was designed in three parts to assess the students' knowledge 
and use of idioms. The first part, consisting of 20 items, was a task to complete the idioms based on the meaning descriptions of these idioms. The second part was a task to match the meanings and the idioms. The third part was a gap-fill task. Questionnaire 1 focused on the students' frequency of using idioms. It consisted of 50 selected idioms with four levels of frequency: never, rarely, sometimes, and often. Questionnaire 2 explored the students' attitudes toward learning and using idioms for communication. This questionnaire contained 10 five-point Likert scale items.

Thirdly, the informants were asked to complete the test and the questionnaires. A week later, six participants were randomly selected to form two focus groups. The purposes of the focus groups were to examine if the students cognitively understood the figurative meaning of the idioms and if they often used these idioms. The data were used to triangulate the findings accumulated from the test and the questionnaires. The focus groups were conducted in English and in Vietnamese. The researcher gave instructions and asked questions first in English and later in Vietnamese. The participants could speak either in English or in Vietnamese as they wished. All the responses in Vietnamese were translated into English by the researcher. The data in these focus groups were confidential; pseudonyms were used in analysis and discussion.

\section{Findings}

The findings showed that the investigated students knew and understood little about the frequently used idioms. Most of the selected idioms were unfamiliar for the students. They rarely learned and used idioms in their conversations, though the majority of the students acknowledged the importance of idioms and learning idioms in their process of learning EFL.

Table 2

Correct Answers Per Idiom

\begin{tabular}{|c|c|c|c|c|c|c|c|}
\hline Group & & \multicolumn{2}{|c|}{$\begin{array}{c}20 \text { idioms in } \\
\text { frequently-used list } \\
\text { (Group 1) }\end{array}$} & $\begin{array}{c}30 \text { idioms selected from idiom } \\
\text { books by Google search } \\
\text { (Group 2) }\end{array}$ & \multicolumn{2}{|c|}{50 idioms } \\
\hline Group & $n$ & Mean & $\%$ & Mean & $\%$ & Mean & $\%$ \\
\hline Year 2 & 27 & 1.3 & $5 \%$ & 4.7 & $17 \%$ & 3.3 & $12 \%$ \\
\hline Year 1 & 47 & 3.3 & $7 \%$ & 7.4 & $16 \%$ & 5.8 & $12 \%$ \\
\hline
\end{tabular}

Table 2 shows the percentage and mean of the students who gave the correct answers to each idiom-related item in the test. The mean and percentage were calculated for the 20 frequently used idioms, for the 30 idioms selected by Google search engine, and overall for the 50 idioms. The percentage of the students who gave the correct answers to each test item was quite low, and there was no significant difference between the results of the freshmen and sophomores. Only $12 \%$ of the students gave the correct answer to each question on average for both groups.

There was a slight difference between the results of the 20 idioms in the frequently-used-idiom list and the 30 idioms selected from the idioms books by Google search. Five percent of 27 sophomores $(M=1.3)$ gave the correct answer per idiom in the former, whereas nearly $17 \%(M$ $=4.7)$ gave the correct answer per question in the latter. For the freshmen, the means are 3.3 $(7 \%)$ and $7.4(16 \%)$, respectively. These figures mean that roughly 3 out of 47 students answered each question correctly for the first 20 questions whereas 7 gave the correct answer per question in the latter 30 questions. These results indicate that the students are more familiar 
with the idioms in textbooks than those on the frequently-used list. These figures seem to indicate that the frequency of use should be considered in selection when teachers and students choose idioms to study.

Table 3

The Students' Scores

\begin{tabular}{|c|c|c|c|c|}
\hline Group & $\%$ & Mean & Mode & Median \\
\hline Year 2 & $12 \%$ & 6.1 & 5 & 5 \\
\hline Year 1 & $12 \%$ & 6.2 & 4 & 4 \\
\hline
\end{tabular}

Table 3 describes the students' test scores. Both Year 1 and Year 2 groups answered $12 \%$ of the questions correctly. On average, each student gave six correct answers out of 50 questions ( $M$ $=6.1$ and 6.2 for sophomores and freshmen, respectively). The mode and median were 5 and 4 , respectively. These numbers revealed that the students' scores were low.

The figures in Tables 2 and 3 were also confirmed by the data from the focus groups. When asked about their knowledge of idioms, Student 1 said "in fact, I am not good at learning idioms. I have known few idioms, so I hardly use idioms in my conversation."

Table 4

Students' Use of Idioms

\begin{tabular}{|c|c|c|c|c|}
\hline & Mean & Mode & Median & $S D$ \\
\hline Year 2 & 1.51 & 1.37 & 1.37 & 0.3 \\
\hline Year 1 & 1.7 & 1.3 & 1.6 & 0.4 \\
\hline Year 1 + Year 2 & 1.6 & 1.3 & 1.5 & 0.4 \\
\hline
\end{tabular}

Table 4 indicates the frequency of using figurative idioms in students' communication. This data came from the four-point Likert scale items asking how often the students used these 50 idioms. They were asked to choose never, rarely, sometimes, or often; the options were coded $1,2,3$, and 4, respectively. The means for using idioms in conversations were 1.51 for sophomores and 1.7 for freshmen. These figures indicate that these idioms were never or rarely used in the students' conversations.

\section{Table 5}

Students' Learning and Using Idioms Versus Students' Desires of Learning and Using Idioms

\begin{tabular}{|c|c|c|c|c|c|c|c|}
\hline & $\begin{array}{c}\text { Usually } \\
(4)\end{array}$ & $\begin{array}{c}\text { Often } \\
(3)\end{array}$ & $\begin{array}{c}\text { Sometimes } \\
(2)\end{array}$ & $\begin{array}{c}\text { Rarely } \\
(1)\end{array}$ & $\begin{array}{c}\text { Never } \\
(0)\end{array}$ & Mean & Mode \\
\hline Idioms learned & $0 \%$ & $8 \%$ & $32 \%$ & $60 \%$ & $0 \%$ & 1.12 & 1 \\
\hline Idioms used & $0 \%$ & $0 \%$ & $20 \%$ & $72 \%$ & $8 \%$ & 1.48 & 1 \\
\hline
\end{tabular}




\section{Table 6}

Students' Desire and Perceptions Toward Learning and Using Idioms in Their Conversations

\begin{tabular}{|c|c|c|c|c|c|c|c|}
\hline & $\begin{array}{c}\text { Strongly } \\
\text { agree } \\
(4)\end{array}$ & $\begin{array}{c}\text { Agree } \\
(3)\end{array}$ & $\begin{array}{c}\text { Neutral } \\
(2)\end{array}$ & $\begin{array}{c}\text { Disagree } \\
(1)\end{array}$ & $\begin{array}{c}\text { Strongly } \\
\text { disagree } \\
(0)\end{array}$ & Mean & Mode \\
\hline $\begin{array}{c}\text { Learning idioms is } \\
\text { important }\end{array}$ & $8 \%$ & $60 \%$ & $32 \%$ & $0 \%$ & $0 \%$ & 2.76 & 3 \\
\hline $\begin{array}{c}\text { I want to use } \\
\text { idioms to } \\
\text { communicate }\end{array}$ & $32 \%$ & $52 \%$ & $16 \%$ & $0 \%$ & $0 \%$ & 3.16 & 3 \\
\hline
\end{tabular}

Tables 5 and 6 compare the students' actual learning and use of idioms with their desires and perceptions of learning and using idioms to communicate. It is likely that although the students rarely learned $(M=1.12 ;$ mode $=1)$ and used idioms $(M=1.48 ;$ mode $=1)$, they wanted to learn $(M=2.76$; mode $=3)$ and be able to use idioms to communicate $(M=3.16$, mode $=3)$. The significant gap between the reality and the desires of learning and using idioms reflected the inadequate process of learning of idioms. Sixty percent of students rarely learned idioms while over $60 \%$ agreed or strongly agreed that learning idioms was important in their learning process. Meanwhile, just under $80 \%$ of the students rarely or never used idioms in their conversations. In contrast, well over $80 \%$ of the students wanted to use idioms.

It can be seen from the findings that the students' perceptions of learning and using idioms have been changing since they entered the university. As Student 2 expressed,

Before I went to university, I used to think idioms were not important. And the teachers rarely taught us about idioms. When I entered the university I started learning something about idioms. And then I changed my mind. I think that learning idioms is very good. I think students should be encouraged to learn idioms more and more to use idioms as well as possible.

Most of the participants in the focus groups agreed that idioms were part of the target language. They acknowledged that learning idioms was, moreover, very important, as idioms also contain many cultural values.

In my opinion, learning a language is learning about its culture, so to learn a language effectively, we should learn about its culture. Idioms are part of the culture so, for me, learning idioms is very important and interesting. (Student 3)

However, they also admitted that they rarely or never used idioms for several reasons. First, they had difficulty remembering the idioms. As Student 6 responded, "I make mistakes when I remember and recall idioms as long phrases to express my ideas." Student 4 agreed by saying "Because it is a fixed phrase, so I can't change it, we have to remember that long phrases. If we change any word in that group, it's wrong." Second, the students are likely not encouraged to use and learn idioms in practice. Student 5 said that "in class, we don't pay much attention to idioms; sometimes we note down some idiomatic phrases in the listening and speaking sessions with its explanation, but we do not fully understand its uses." Third, they probably did not learn idioms systematically to fully understand the meaning, use, and context of each idiom. Student 1 admitted that 
although learning idioms is interesting, we meet difficulties in learning idioms because it's different in thinking when we use idioms. Some metaphors in idioms are not familiar to our culture. We do not know whether we use this or that idiom in this or that context is appropriate or not.

Student 3 stated, "I don't use idioms because I am not sure it's right or wrong in terms of meaning and context." Fourth, their process of learning idioms appeared sporadic and unsystematic. As Student 6 noted, "I learn idioms just for fun. Whenever I want to find or learn more idioms, I read them in the books such as novels or newspapers, [or] watching films."

\section{Discussion}

The students' figurative idiomatic competence is extremely low from different perspectives. Firstly, they seem to be very limited in their ability to recognize, understand, and use basic figurative idioms. The analysis mainly focuses on the students' ability at these low levels. Secondly, in comparison with Burke's (1988) and Buckingham's (2006) views of idiomatic competence, the investigated students are not able to appropriately communicate with idioms as addressors and addressees. Thirdly, while according to Knowles (2004), the learning process should be grounded from familiarization, recognition, and comprehension to mastery and automaticity, the participants are still struggling with familiarization and recognition. They need more effort to reach automaticity in using idioms. Fourthly, for the two-dimension measurement by Richards (1976) and Nation (2001) focusing on the breadth and depth of idioms, the participants' idiomatic competence is significantly low. Similarly, using the threedimension model by Henriksen (1999), focusing on the quantity, quality and receptiveproductive control, the students' idiomatic competence is considerably limited.

The students have limited knowledge of figurative idioms in their conversations for three main reasons. The first is the underestimation of the importance of idioms in language teaching in Vietnam. Both teachers and students appear to avoid idioms in the process of teaching and learning. In contemporary textbooks in secondary schools in Vietnam (English 10, 11, 12), few idioms are presented in reading or listening passages. Second, language learners are unfamiliar with the move from individual words to chunks. Learning vocabulary in Vietnam tends to mean learning individual words and associating each with a Vietnamese equivalent. This appears to prevent students from remembering multi-unit words such as idiomatic phrases, and later achieving automaticity in Knowles' (2004) learning diagram. Moreover, students do not have adequate repetition and practice over a period of time to step further toward automaticity (Knowles, 2004). Only 24 idioms are introduced in the three textbooks (six in English 10, six in English 11, and twelve in English 12). Among these, only one idiom is on the list of frequently used idioms by Grant (2007) and Liu (2003). These idioms are sporadically presented without any consolidation or practice. Indeed, there are no idiom-related exercises or practice in the textbooks.

If the communication strategies for the negotiation of meaning are integrated into the process of learning idioms, however, language learners become more confident in dealing with not yet known figurative idioms in their interactions. Such negotiation of meaning occurs when "the flow of conversation is interrupted" (Gass \& Selinker, 2008, p. 317) and participants stop the flow of the ongoing conversation to solve communicative troubles. The process may use communication strategies such as clarification requests, recasts, confirmation requests, or comprehension checks. These communication strategies can be integrated into the process of learning idioms. For example, language learners can use one of these strategies to request conversational help when miscommunication occurs due to a lack of figurative idiom knowledge during their conversation. Long's (1996) interaction hypothesis argued for the value 
of interaction in second language acquisition, and a more recent study (Mackey, Abbuhl, \& Gass, 2012) has also emphasized the strong connection between interaction and learning. Therefore, the integration of communication strategies for negotiation of meaning into learning idioms helps students have a deeper understanding of the use and the meaning of an idiom and assists learners in learning a language as a whole.

\section{Limitations of the Study}

The current study is still in the process of test design. If item difficulty and discrimination had been analyzed before the data collection period, the reliability of the findings would have been increased. Additionally, test items did not focus on the use of idioms in real communication either in class or outside class. Another limitation concerns extraneous variables such as the students' learning context and background. In the test, there was one item that almost all participants in Year 1 answered correctly because they had learnt this idiom in class a short time before the test. Despite these limitations, this study raises an alert about the low idiomatic competence of language learners in EFL contexts. Future studies should explore learners' ability to use idioms in conversation. Also, longitudinal studies should be conducted to comprehensively assess the idiomatic competence of EFL language learners.

\section{Conclusion}

The study focuses both on the figurative idiomatic competence of EFL learners in the dual role of language learner and pre-service teacher and the low idiomatic competence of other EFL learners. The investigated students knew and understood little about frequently used idioms. The majority of the selected idioms were unfamiliar to the students. Most of the students rarely learned and used idioms in their conversations although they acknowledged the importance of idioms and learning idioms in the process of learning English in EFL contexts. Their poor idiomatic competence was consequently derived from a lack of exposure to idiomatic language in their learning programs, inadequate guidance in learning and using idioms from teachers, and an insufficient habit of learning idioms as phrases and chunks.

The analysis also uncovers part of the learners' desires and abilities to learn idiomatic expressions, which language educators, teachers, and policy makers may want to consider when designing an English course or making a language policy. The investigation also urges EFL teachers and syllabus designers to give idioms a higher priority in their language teaching and learning programs.

The study additionally argues that figurative idioms should be inclusively taught with the skills of negotiation of meaning as a new pedagogical method for teaching figurative idioms.

Furthermore, learners should learn idioms from the expanding circle of countries where English has not traditionally been used. This idiomatic exposure reflects the tendency of using English in the context of postmodern globalization (Canagarajah, 2006), in which English is no longer the possession of inner-circle English-speaking countries such as the U.K., the U.S.A., and Australia (Kachru, 1992), or outer-circle countries where English has had a traditional role as a second language. Language users may need negotiation skills to facilitate communication in English as a lingua franca to negotiate global and local norms (Canagarajah, 2006; McKay, 2010), especially when communication breakdown occurs. These skills of negotiation of meaning are apparently useful for language learners when they have to deal with figurative idioms, which contain typical cultural values.

To improve the situation of learning idioms, both teachers and students should be aware of the significant role of figurative idiomatic expressions in the language learning process. Teachers 
and students should have clear criteria of idiom selection and idiom teaching aspects so that students are able to learn and become familiar with frequently used idioms and their contexts. Students should be exposed to idioms from inner- and expanding circle contexts as well. In addition, communicative strategies for negotiation of meaning should be integrated into the process of learning idioms to help students overcome breakdowns during interactions caused by misunderstanding figurative idioms. Consequently, they will be more confident in communicating with figurative idioms in everyday conversations. 


\section{References}

British Council. IEL TS speaking band descriptors (public version). Retrieved July 18, 2012, from http://www.britishcouncil.org/srilanka-exams-ielts-descriptor-speaking.pdf

Brown, J. D., \& Rodgers, T. S. (2002). Doing second language research. Oxford: Oxford University Press.

Buckingham, L. (2006). A multilingual didactic approach to idioms using a conceptual framework. Language Design, 8, 35-45.

Burke, D. (1988). Without slang and idioms, students are in the dark! ESL Magazine, 1(5), 2023.

Canagarajah, S. (2006). Changing communicative needs, revised assessment objectives: testing English as an international language. Language Assessment Quarterly, 3(3), 229-242. http://dx.doi.org/10.1207/s15434311laq0303_1

Canale, M., \& Swain, M. (1980). Theoretical bases of communicative approaches to second language teaching and testing. Applied Linguistics, /1), 1-47. http://dx.doi.org/10.1093/applin/l.1.1

Celce-Murcia, M. (1995). Communicative competence: A pedagogically motivated model with content specifications. Issues in Applied Linguistics, 6(2), 5-35.

Celce-Murcia, M. (2008). Rethinking the role of communicative competence in language teaching. In E. Alcón Soler \& P. Safont Jordà (Eds.), Intercultural language use and language learning (pp. 41-57). Dordrecht, The Netherlands: Springer.

Chomsky, N. (1965). Aspects of the theory of syntax. Cambridge, Massachusetts: MIT Press.

Cooper, T. C. (1999). Processing of idioms by L2 learners of English. TESOL Quarterly, 33(2), 233-262. http://dx.doi.org/10.2307/3587719

Council of Europe. (2012). The common European framework in its political and educational context Retrieved from http://www.coe.int/t/dg4/linguistic/Source/Framework_en.pdf

Fernando, C. (1996). Idioms and idiomaticity. Oxford, England: Oxford University Press.

Gass, S. M., \& Selinker, L. (2008). Second language acquisition : An introductory course (3rd ed.). New York, New York: Routledge / Taylor and Francis Group.

Grant, L. E. (2007). In a manner of speaking: Assessing frequent spoken figurative idioms to assist ESL/EFL teachers. System, 35(2), 169-181. http://dx.doi.org/10.1016/j.system.2006.05.004

Grant, L. E., \& Bauer, L. (2004). Criteria for re-defining idioms: Are we barking up the wrong tree? Applied Linguistics, 25(1), 23-61. http://dx.doi.org/10.1093/applin/25.1.38

Henriksen, B. (1999). Three dimensions of vocabulary development. Studies in Second Language Acquisition, 21(2), 303-317. http://dx.doi.org/10.1017/S0272263199002089

Hymes, D. (1972). On communicative competence. In J. Pride \& J. Holmes (Eds.), Sociolinguistics: Selected readings (pp. 269-293). Harmondsworth, England: Penguin.

Kachru, B. (1992). The other tongue: English across cultures (2nd ed.). Urbana, Illinois: University of Illinois Press.

Knowles, L. (2004). The evolution of CALL. The Journal of Communication \& Education: Language Magazine, August. Retrieved from http://mebides.meb.gov.tr/files/bilgisayar_destekli_dil_egitimi.pdf

Lennon, P. (1998). Approaches to the teaching of idiomatic language. International Review of Applied Linguistics in Language Teaching, 36(1), 11-30. http://dx.doi.org/10.1515/iral.1998.36.1.11

Liu, D. (2003). The most frequently used spoken American English idioms: A corpus analysis and its implications. TESOL Quarterly, 374), 671-700. http://dx.doi.org/10.2307/3588217

Long, M. (1996). The role of the linguistic environment in second language acquisition. In W. Ritchie \& T. Bhatia (Eds.), Handbook of second language acquisition (pp. 413-468). New York, New York: Academic Press. 
Mackey, A., Abbuhl, R., \& Gass, S. (2012). Interactionist approach. In S. M. Gass \& A. Mackey (Eds.), The Routledge handbook of second language acquisition (pp. 7-23). London, England; New York, New York: Routledge.

Makkai, A. (1972). Idiom Structure in English. The Hague, the Netherlands: Mouton. http://dx.doi.org/10.1515/9783110812671

McKay, S. L. (2010). English as an international language. In N. H. Hornberger \& S. L. McKay (Eds.), Sociolinguistics and Language Education (pp. 89-115). Bristol, England: Multilingual Matters.

Nation, I. S. P. (2001). Learning vocabulary in another language. New York, New York: Cambridge University Press. http://dx.doi.org/10.1017/CBO9781139524759

Prodromou, L. (2003). Idiomaticity and the non-native speaker. English Today, 19(2), 42-48. http://dx.doi.org/10.1017/S0266078403002086

Richards, J. C. (1976). The role of vocabulary teaching. TESOL Quarterly, 10(1), 77-89. http://dx.doi.org/10.2307/3585941

Simpson, R., \& Mendis, D. (2003). A corpus-based study of idioms in academic speech. TESOL Quarterly, 373), 419-441. http://dx.doi.org/10.2307/3588398

Stake, R. E. (1995). The art of case study research. Thousand Oaks, California: Sage Publications.

Tran, H. Q. (2012). An explorative study of idiom teaching for pre-service teachers of English. English Language Teaching, 5(12), 76-86.

Vasiljevic, Z. (2011). Using conceptual metaphors and L1 definitions in teaching idioms to non native speakers. The Journal of Asia TEFL, 8(3), 135-160. http://dx.doi.org/10.1177/1362168811412025

Wray, A. (2000). Formulaic sequences in second language teaching: principle and practice. Applied Linguistics, 21(4), 463-489. http://dx.doi.org/10.1093/applin/21.4.463

Zareva, A., Schwanenflugel, P., \& Nikolova, Y. (2005). Relationship between lexical competence and language proficieny: Variable sensitivity. Studies in Second Language Acquisition, 274), 567-595. http://dx.doi.org/10.1017/S0272263105050254

Zyzik, E. (2009). Teaching and learning idioms: The big picture. CLEAR, 13(2), 1-7.

Zyzik, E. (2011). Second language idiom learning: The effects of lexical knowledge and pedagogical sequencing. Language Teaching Research, 15(4), 413-433. 


\section{Appendix \\ Idiom Test}

Dear students,

I am conducting a study on idiomatic competence of language learners at the Faculty of English. Your responses are completely anonymous and confidential. Please feel free to respond to the questions. Your responses will be of great value to the findings. Thanks a million for your contribution!

\section{PLEASE WRITE ALL YOUR ANSWERS ONTO THE ANSWER SHEET!}

I. Write ONE or TWO words to complete the idioms based on their meaning in the next column.

\begin{tabular}{|c|c|}
\hline Idioms & Meaning \\
\hline 1. A piece & A thing that is very easy to do \\
\hline 2. Not my cup & Not what I like or am interested in \\
\hline 3. __ to the fire & Make a bad situation worse \\
\hline 4. _ your mind & To decide what to choose \\
\hline 5. Off__ of my head & Recall / speak something without preparation \\
\hline 6. Have__ in & The right to express your opinion and influence decisions \\
\hline 7. All of & Quickly, unexpectedly \\
\hline 8. Be over & Too difficult or complicated for me to understand \\
\hline 9. _ of thumb & $\begin{array}{l}\text { A practical method of doing or measuring something, } \\
\text { usually based on past experience, not based on science } \\
\text { or exact measurement }\end{array}$ \\
\hline 10. Push the & $\begin{array}{l}\text { Go beyond the limits of what is allowed or thought to be } \\
\text { possible }\end{array}$ \\
\hline 11. Bits and & Small objects or idioms of various kinds \\
\hline 12. Thinking on & $\begin{array}{l}\text { To be able to think and react to things very quickly and } \\
\text { effectively without any preparation }\end{array}$ \\
\hline 13. Draw the & Distinguish between two closely related ideas \\
\hline 14. Take & Believe me, trust me, I am telling you the truth \\
\hline 15. It goes & Used to say that something proves something \\
\hline 16. Down & All the way, throughout \\
\hline 17. Get to the & Figure everything out \\
\hline 18. Have & Change your opinion after thinking about something again \\
\hline 19. Out of & In a way that was not expected, unexpectedly \\
\hline 20. I can take it or & I do not hate something, but don't particularly like it either \\
\hline
\end{tabular}


II. Match the meaning and the idiom.

\begin{tabular}{|l|l|}
\hline 1. if all else fails & A. $\quad$ very practical \\
\hline 2. in your shoes & B. written, not just a spoken agreement \\
\hline 3. on top of the world & C. $\quad$ something you say before stating a very important fact or \\
\hline 4. make it big & D. succeed, become famous \\
\hline 5. snowed under & E. $\quad$ very busy at the moment \\
\hline 6. speak your mind & F. a long time from now \\
\hline 7. cross your mind & G. be an activity or job you do to get the money \\
\hline 8. in the long run & H. is totally harmless and would never hurt anyone \\
\hline 9. at the end of the day & I. $\quad$ very happy indeed \\
\hline 10. black and white & J. in your position \\
\hline 11. wouldn't hurt a fly & K. state your opinion very clearly and openly \\
\hline 12. be your bread and butter & L. $\quad$ extremely happy \\
\hline 13. middle of the road & M. has no radical views \\
\hline 14. down to earth & N. if all other plans do not work \\
\hline 15. over the moon & O. think about something for a short time \\
\hline
\end{tabular}


III. Use the following idioms in their correct situations.

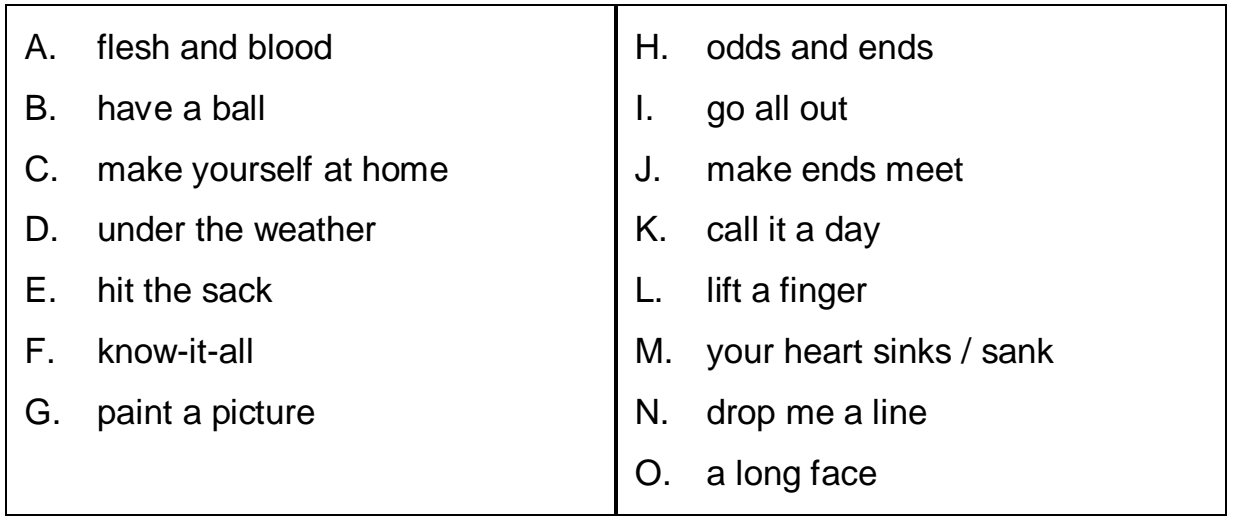

1. when I opened the letter and realized I had not been accepted into graduate school.

2. Little Mikey had when he was told he couldn't go outside to play

3. I'm so tired that the only thing I want to do is take a shower and

4. This weekend I stayed at home and did some around the house.

5. Look, it's already 4:30. Time to

6. Thanks so much for inviting us to the party. We really

7. Why don't you some time to let me know how you're going?

8. All of our came to the big family reunion.

9. I'm glad you could come. Please

10. Jane's head and neck hurt, and her nose is stuffy. She must be

11. Every month we have to plan our budget carefully in order to

12. No one listens to Greg at meetings because he always acts like such a

13. The nation's leading economist about continued growth in the automobile industry.

14. No one will complain if you but still don't succeed.

15. Mrs. Waters is upset with her husband because he doesn't around the house on the weekend. He just watches sports programs on TV. 